\section{$\underset{\text { hommes }}{\text { \& migrations }}$}

\section{Hommes \& migrations}

Revue française de référence sur les dynamiques

migratoires

\section{$1294 \mid 2011$}

L'intégration en débat

\title{
Les neiges du Kilimandjaro
}

Film français de Robert Guédiguian

\section{André Videau}

\section{(2) OpenEdition \\ 1 Journals}

\section{Édition électronique}

URL : http://journals.openedition.org/hommesmigrations/593

DOI : 10.4000/hommesmigrations.593

ISSN : 2262-3353

\section{Éditeur}

Musée national de l'histoire de l'immigration

\section{Édition imprimée}

Date de publication : 1 novembre 2011

Pagination : 138

ISSN : 1142-852X

\section{Référence électronique}

André Videau, "Les neiges du Kilimandjaro », Hommes \& migrations [En ligne], 1294 | 2011, mis en ligne le 29 mai 2013, consulté le 22 septembre 2020. URL : http://journals.openedition.org/

hommesmigrations/593; DOI : https://doi.org/10.4000/hommesmigrations.593

Ce document a été généré automatiquement le 22 septembre 2020.

Tous droits réservés 


\title{
Les neiges du Kilimandjaro
}

\author{
Film français de Robert Guédiguian
}

\section{André Videau}

1 Au détour de la cinquantaine, Marie-Claude et Michel ont toujours le cœur à gauche (Ariane Ascaride et Jean-Pierre Darroussin chez Guédiguian comme chez eux). Même si les lendemains ne chantent plus guère et que les avant-hier se consolent avec une romance indélébile de Pascal Danel, plus nostalgique et langoureuse que La Carmagnole. Ils ont les récompenses d'une vie de travail modeste avec une maison au flanc de l'Estaque et ses escaliers en éventail qui distribuent l'ombre, le soleil et la vue sur la mer. De quoi attendre la retraite en recevant enfants et petits-enfants pour la baignade, le pastis et le barbecue dominical.

2 Mais la précarité survient avec un plan de licenciements auquel Michel, délégué syndical CGT, ne peut se soustraire. Il faut avoir recours à quelques expédients pour joindre les deux bouts. Distribuer des prospectus, garder les minots, cuisiner, bricoler, s'attaquer enfin à la véranda de Gilles (Adrien Jolivet), recevoir les intimes (surtout Raoul et Denise, Gérard Meylan et Marilyne Canto, les plus proches parents, les indéfectibles complices). Marie-Claude et Michel vont pouvoir fêter dignement leurs trente ans de mariage, partir pour le Kenya ou la Tanzanie et le fameux Kilimandjaro !

3 Leur bonheur va voler en éclats avec l'irruption en pleine partie de cartes de deux énergumènes armés et masqués. Ils sont battus, dépouillés, humiliés. Ils comprendront vite à travers une belle histoire de bédé et de petits frères, où Guédiguian déploie toute sa fougue romanesque, que les agresseurs sont de jeunes collègues de travail, sans foi, ni loi. Leur monde s'écroule une seconde fois. Aux tentations nihilistes ou vindicatives, l'auteur va opposer une poignante leçon d'humanité. On regagne l'Estaque avec le sentiment de la proximité d'une vie meilleure. Ça s'arrose. Tournée générale de Métaxas pour se requinquer. Appelez le serveur: Pierre Niney. C'est un poète et un philosophe. Un nouveau venu dans la troupe de Guédiguian. 